\title{
PENGARUH PERSEPSI KEMUDAHAN DAN PERSEPSI MANFAAT TERHADAPNIAT BELI ULANG SECARA ONLINE DENGAN KEPUASAN SEBAGAI VARIABEL INTERVENING
}

\author{
KHOIRUL BASYAR, SANAJI \\ Jurusan Manajemen, Fakultas Ekonomi, Universitas Negeri Surabaya, \\ Kampus Ketintang, Surabaya 60231 \\ E-mail: kbasyar47gmail.com
}

\begin{abstract}
Abstrack:
The purpose of this study to analyze the effect of perceived ease of use and perceived usefulness on online repurchase intention that mediating of satisfaction variable. Samples taken as many as 210 peoples. Measuring instruments used are questionnaire data analysis using path analysis.The results showed that the perceived ease of use dan perceived usefulness having a positive and significant influence towards satisfaction. Perceived ease of use dan perceived usefulness having a positive and significant effect against online repurchase intention. The satisfaction of having a positive and significant effect against online repurchase intention.

Keywords: Perceived Ease of Use, Perceived Usefulness, Online Repurchase Intention, Satisfaction.
\end{abstract}

\section{PENDAHULUAN}

Perkembangan bisnis e-commerce di Indonesia melesat dalam tiga tahun terakhir. Hasil riset yang diprakarsai oleh Asosiasi E-commerce Indonesia (idEA), Google Indonesia, dan TNS (Taylor Nelson Sofres) tahun 2015 dan dipublikasikan oleh www.jpnn.com memperlihatkan bahwa tahun 2013 nilai pasar e-commerce Indonesia mencapai US $\$ 8$ miliar (Rp 94,5 triliun), padatahun 2014 mencapai US\$12 miliar (Rp 141 triliun), padatahun 2015 mencapai US\$20 miliar (Rp 236 triliun) dan di tahun 2016 diprediksikan menjadi US\$25 miliar ( $R p 295$ triliun).

Survei yang dilakukan Rakuten Belanja Online dan Redshift Research yang dipublikasikan oleh bisnis.com tahun 2013 diketahui sebanyak 84\% responden di Indonesia tidak puas dengan pengalaman berbelanja online mereka. Perilaku konsumen yang seperti ini mencerminkan bahwa adanya fenomena rendahnya kepuasan dalam berbelanja online namun pertumbuhan belanja online di Indonesia disetiap tahunnya mengalami peningkatan.

Survei dari Asosaiasi PenggunaJasa Internet Indonesia

(APJII) dipublikasikan www.apjii.or.id pada tahun 2014 dimana konsumen di Indonesia sebanyak $72,7 \%$ pengguna internet menyatakan belum pernah melakukan belanja online. Faktor utama yang menyurutkan niat pengguna internet melakukan belanja online adalah karena merekaberanggapan akan memakan proses yang lama (59.5\%).

Hal ini menunjukkan bahwa berbelanja online itu tidak mudah, karena prosesnya lama.Dan hal tersebut menjadi tidak menguntungkan bagi konsumen yang melakukan berbelanja 


\section{Khoirul Basyar, Sanaji - Pengaruh Persepsi Kemudahan Dan Persepsi Manfaat ...}

online.Hal ini menunjukkan fenomena bahwa dalam berbelanja online itu tidak mudah, karena prosesnya lama.

Untuk menyelesaikan fenomena yang terjadi dapat digunakan teori Technology Acceptance Model (TAM) digunakan sebagai dasar dari berbagai studi sisteminformasi teknologi yang dapat digunakan untuk menjawab fenomena yang terjadi (Pavlou, 2003). Davis (1989) menjelaskan bahwa TAM, teori sistem informasi yang membuat model tentang bagaimana pengguna mau menerima dan menggunakan teknologi. Model ini mengusulkanbahwa ketika pengguna ditawarkan untuk menggunakan suatu sistem yang baru, sejumlah faktor memengaruhi perilaku mereka tentang bagaimana dankapan akan menggunakan sistem tersebut, khususnya dalam hal perceived usefulness danperceived ease of use.

Menurut Wen et al., (2011) menyebutkan bahwa persepsi kemudahan itu dimana konsumen merasakan bahwa belanja di toko berbasis web akan meningkatkan belanjanya serta sejauh mana konsumen merasakan kemudahan interaksi dengan situs web dan dapat menerima informasi produk yang ia butuhkan. Wen et al., (2011) menyebutkan persepsi manfaat sebagai penilaian konsumen terhadap manfaat informasi produk yang dibutuhkan dan dirasakan pada saat berbelanja di toko berbasis web.

Menurut Shankar et al., (2003, dalam Siyamtinah dan Hendar, 2015) kepuasan secara online dimana hubungan khusus yang berasal dari efek serangkaian pertemuan layanan diskrit atau transaksi dengan vendor onlineselama periode waktu tertentu. Dalam hal ini termasuk mencari, membeli, dan menggunakan produk.Kepuasan konsumen merupakan faktor yang sangat penting dalam membentuk perilaku niat beli ulang pada pembelanjaan online(Park et al., 2010, dalam Siyamtinah dan Hendar, 2015). Sehingga kepuasan konsumen akan mempengaruhi terbentuknya niat beli ulang pada pembelanjaan online (Park et al., 2010 dalam Siyamtinah dan Hendar, 2015).

Menurut Hellieret al., (2003, dalam Sai dan Sirion, 2014) niat pembelian ulang dimana penilaian individu dari pembelian kembali produk atau jasa tertentu dari bisnis yang sama, dengan mempertimbangkannya posisi saat ini dan mungkin mempertimbangkan yang akan datang.

Berdasarkan latar belakang diatas, maka penting dilakukan penelitian untuk menganalisis pengaruh persepsi kemudahan dan persepsi manfaat terhadap niat beli ulang secaraonline dengan kepuasan sebagai variabel intervening (studi pada mahasiswa Universitas Negeri Surabaya.

\section{KAJIAN PUSTAKA}

\section{Persepsi Kemudahan (Perceived Ease of Use)}

Menurut Davis (1989) persepsi kemudahan merupakan tingkatan di mana seseorang percaya bahwa penggunaan sistem tertentu dapat mengurangi usaha seseorang dalam mengerjakan sesuatu. Menurut Wibowo (2006, dalam Yolanda, 2013) persepsi kemudahan didefinisikan sebagai suatu ukuran dimana seseorang percaya bahwa teknologi tersebut dapat dengan mudah 


\section{BISMA - Bisnis dan Manajemen -Volume 8 No. 2 Februari 2016}

dipahami dan digunakan. Menurut Hartono (2007, dalam Shomad, 2013) persepsi kemudahan didefinisikan sebagai sejauhmana seseorang percaya bahwa menggunakan suatu teknologi akan bebas dari usaha. Pengukuran persepsi kemudahan mengadaptasi dari penelitian Pavlou (2003) yaitu situs yang jelas dan dapat dimengarti, tidak memerlukan usaha yang berlebih, mudah menemukan informasi yang dibutuhkan dan mudah untuk digunakan.

\section{Persepsi Manfaat (Perceived Usefulness)}

Menurut Davis (1989) persepsi manfaat merupakan sejauh mana orang percaya bahwa menggunakan suatu teknologi akan meningkatkan kinerja dari pekerjaannya. Menurut Wibowo (2008, dalam Yolanda, 2013) persepsi manfaat merupakan suatu ukuran dimana penggunaan suatu teknologi dipercaya akan mendatangkan manfaat bagi orang yang menggunakannya.

Menurut Wen et al., (2011) mendefinisikan persepsi manfaat sebagai penilaian konsumen terhadap manfaat informasi produk yang dibutuhkan dan dirasakan pada saat berbelanja di toko berbasis web. Pengukuran persepsi manfaat mengadaptasi dari penelitian Trisnawati dkk., (2012) yaitu internet memudahkan berbelanja secara cepat, internet membuat keputusan pembelian yang lebih baik, internet sebagai belanja yang lebih berguna, belanja internet menghemat uang, internet lebih mudah untuk melakukan pembelian.

\section{Kepuasan (E-Satisfaction)}

Menurut Shankar et al., (2003, dalam Siyamtinah dan Hendar,2015)kepuasan konsumen adalah hubungan khusus yang berasal dari efek serangkaian pertemuan layanan diskrit atau transaksi dengan vendor online selama periode waktu tertentu.Dalam hal ini termasuk mencari, membeli, dan menggunakan produk.Menurut Wen et al., (2011) kepuasan didefinisikan sebagaihasil ringkas keadaan psikologis ketika perasaan yang melingkupi harapantidak diinginkan digabungkan dengan perasaan konsumen sebelumnya tentang pengalaman penggunaan.Pengukuran kepuasan mengadaptasi dari penelitian Wen et al., (2011) yaitu saya sangat puas dengan keseluruhan pengalaman berbelanja online, saya sangat senang dengan keseluruhan pengalaman berbelanja online, saya sangat terpuaskan dengan keseluruhan pengalaman berbelanja online, saya sangat senang sekali dengan keseluruhan pengalaman berbelanja online.

\section{Niat Beli Ulang Secara Online (online repurchase intention)}

Menurut Hellieret al., (2003, dalam Sai dan Sirion ,2014) niat pembelian ulang adalah penilaian individu dari pembelian kembali produk ataujasa tertentu dari bisnis yang sama, dengan mempertimbangkannya posisi saat ini dan mungkin mempertimbangkan. Fang,et al., (2011, dalam Andriani , 2015) mengemukakan bahwa niat beli ulang mengacu pada probabilitas subyektif bahwa seseorang individu akan terus membeli produk dari penjual online atau toko dimasa depan. Pengukuran variabel niat beli ulang secara online dalam penelitian ini mengadaptasi dari pengukuran niat pembelian ulang online menurut Wen et al., (2011) yaitu saya 
lebih melanjutkan belanja secara online daripada menghentikannya, saya lebih menggunakan belanja secara online daripada belanja secara tradisional, saya akan melanjutkan belanja secara online sebanyak mungkin.

\section{Persepsi Kemudahan dan Kepuasan}

Dalam penelitian Purwohandoko dkk., (2015) menyebutkan bahwa terdapat pengaruh positif antara persepsi kemudahan dengan kepuasan. Hasil tersebut menunjukkan bahwa persepsi kemudahan dapat menimbulkan individu menjadi semakin puas terhadap penggunaan teknologi baru. Menurut penelitian Tuet al., (2012) menyebutkan bahwa terdapat pengaruh yang signifikan antara persepsi kemudahan dengan kepuasan. Hasil tersebut menunjukkan bahwa persepsi kemudahan dapat membuat konsumen puas.

\section{Persepsi Manfaat dan Kepuasan}

Penelitian yang dilakukan Trisnawatidkk., (2012) menyebutkan bahwa terdapat pengaruh positif antara persepsi manfaat terhadap kepuasan, artinya semakin baik persepsi manfaat, maka kepuasan juga akan semakin meningkat baik pada produk online Fesh Shop.

Hasil penelitian yang dilakukan Wen, et al., (2011) yang memberikan hasil bahwa variabel persepsi kemudahan secara signifikan berpengaruh positif terhadap kepuasan.

Dalam penelitian Purwohandoko dkk., (2015) menyebutkan bahwa terdapat pengaruh positif antara persepsi manfaat dengan kepuasan. Hasil tersebut menunjukkan bahwa persepsi manfaat dapat menimbulkan individu menjadi semakin puas terhadap penggunaan teknologi baru.

\section{Kepuasan dan Niat Beli Ulang Secara Online}

Penelitian yang dilakukan Trisnawati, dkk., (2012) menyebutkan bahwa terdapat pengaruh positif antara kepuasan dengan niat pembelian ulang secara online. Hasil penelitian tersebut menunjukkan bahwa semakin baik kepuasan maka niat pembelian ulang secara onlinejuga akan semakin meningkatbaik pada produk online Fesh Shop.

Hasil penelitian ini sejalan dengan penelitian yang dilakukan oleh Wen,et al., (2011) yang memberikan hasil penelitian bahwa variabel kepuasan secara signifikan berpengaruh positif terhadap niat pembelian ulang secar online.

Menurut penelitian dari Siyamtinah dan Hendar (2015) yang memberikan hasil penelitian bahwa variabel kepuasansecara signifikan berpengaruh positif terhadap niat pembelian ulang secara online. Hasil tersebut menunjukkan semakin konsumen puas maka akan semakin positif niat pembelian ulang secara online.

\section{Persepsi Kemudahan dengan Niat Beli Ulang SecaraOnline}

Har dan Eze (2011) dalam penelitiannya memberikan hasil bahwa persepsi kemudahan berpengaruh positif terhadap niat pembelian ulang secara online. Hasil tersebut menunjukkan semakin baik persepsi kemudahan maka akan semakin positif niat pembelian ulang secara online. Menurut penelitian Adiutama dan Santika (2013) dalam penelitiannya memberikan hasil bahwa 


\section{BISMA - Bisnis dan Manajemen -Volume 8 No. 2 Februari 2016}

persepsi kemudahan penggunaan berpengaruh positif dan signifikanterhadap niat berbelanja kembali pada situs jual beli online Tokobagus.com, hal ini berarti semakin tinggi persepsi kemudahan penggunaan maka niat berbelanja kembali pada Tokobagus.com juga akan meningkat.

\section{Persepsi Manfaat dengan Niat Beli Ulang Secara Online}

Penelitian yang dilakukan Trisnawati, dkk., (2012) menyebutkan bahwa terdapat pengaruh positif antara persepsi manfaat dengan niat pembelian ulang online. Hasil penelitian ini menunjukkan persepsi manfaat yang dirasakan oleh para konsumen adalah konsumen yang telah mencapai tugas belanja yang efisien akan menunjukkan bahwa konsumen tersebut akan melakukan pembelian ulang terhadap produk Fesh Shop. Har dan Eze (2011) dalam penelitiannya memberikan hasil bahwa persepsi manfaat berpengaruh positif terhadap niat pembelian ulang online. Hasil penelitian ini sejalan dengan penelitian yang dilakukan oleh Wen et al., (2011) yang memberikan hasil bahwa variabel persepsi manfaat secara signifikan berpengaruh positif terhadap niat beli ulang secara online.

\section{Hipotesis}

Berdasarkan kajian teoritis dan penelitian terdahulu, maka hipotesis dalam penelitian ini adalah sebagai berikut:

H1: Terdapat pengaruh persepsi kemudahan terhadap kepuasan.

$\mathrm{H} 2$ : Terdapat pengaruh persepsi manfaat terhadap kepuasan.

H3: Terdapat pengaruh kepuasan terhadap niat beli ulang secara online.
H4: Terdapat pengaruh persepsi manfaat terhadap niat beli ulang secara online.

H5: Terdapat pengaruh persepsi kemudahan terhadap niat beli ulang secara online.

\section{METODE PENELITIAN}

Penelitian ini menggunakan rancangan riset konklusif dengan tujuan menguji hipotesis yang spesifik dan hubungan spesifik.Jenis penelitian yang digunakan dalam penelitian ini adalah penelitian kausal.

Populasi dalam penelitian ini adalah mahasiswa Universitas Negeri Surabaya yang masih aktif semester ganjil tahun ajaran 2015/2016 dengan karakteristik usia minimal 18 tahun dan maksimal 25 tahun dan pernah membeli secara online minimal 2 kali dalam kurun waktu 6 bulan terakhir. Teknik pengambilan sampel yang digunakan adalah non probability sampling, dengan jumlah responden sebanyak 210.Data yang digunakan berupa data primer yang diperoleh melalui penyebaran angket.

Penelitian ini menggunakan tiga variabel yang terdiri dari variabel bebas, dan variabel terikat dan variabel intervening. Variabel bebas yaitu persepsi kemudahan dan persepsi manfaat, variabel terikat yaitu niat beli ulang secaraonline dan variabel intervening yaitu kepuasan.

Persepsi kemudahan merupakan tingkatan di mana seseorang percaya bahwa penggunaan sistem tertentu dapat mengurangi usaha seseorang dalam mengerjakan sesuatu (Davis,1989).Pengukuran variabel persepsi kemudahan dalam penelitian ini mengadaptasi dari pengukuran persepsi 


\section{Khoirul Basyar, Sanaji - Pengaruh Persepsi Kemudahan Dan Persepsi Manfaat ...}

kemudahan menurut penelitian Pavlou (2003)yaitu situs yang jelas dan dapat dimengarti, tidak memerlukan usaha yang berlebih, mudah menemukan informasi yang dibutuhkan dan mudah untuk digunakan.

Menurut Davis (1989) persepsi manfaat merupakan sejauh mana orang percaya bahwa menggunakan suatu teknologi akan meningkatkan kinerja dari pekerjaannya. Pengukuran variabel persepsi manfaat dalam penelitian ini mengadaptasi dari pengukuran persepsi manfaat menurut Trisnawati, dkk., (2012) yaitu internet memudahkan berbelanja secara cepat, internet membuat keputusan pembelian yang lebih baik, internet sebagai belanja yang lebih berguna, belanja internet menghemat uang, internet lebih mudah untuk melakukan pembelian.

Menurut Wen et al., (2011) kepuasan didefinisikan sebagai hasil ringkas keadaan psikologis ketika perasaan yang melingkupi harapan tidak diinginkan digabungkan dengan perasaan konsumen sebelumnya tentang pengalaman penggunaan. Pengukuran variabel kepuasan dalam penelitian ini mengadaptasi dari pengukuran kepuasan menurut penelitian Wen et al., (2011) yaitu saya sangat puas dengan keseluruhan pengalaman berbelanja online, saya sangat senang dengan keseluruhan pengalaman berbelanja online, saya sangat terpuaskan dengan keseluruhan pengalaman berbelanja online, saya sangat senang sekali dengan keseluruhan pengalaman berbelanja online.

Fang et al., (2011, dalam Andriani, 2015) mengemukakan bahwa niat beli ulang mengacu pada probabilitas subyektif bahwa seseorang individu akan terus membeli produk dari penjual online atau toko dimasa depan. Pengukuran variabel niat beli ulang secara online dalam penelitian ini mengadaptasi dari pengukuran niat pembelian ulang online menurut Wen,et al., (2011) yaitu saya lebih melanjutkan belanja secara online dari pada menghentikannya, saya lebih menggunakan belanja secara online daripada belanja secara tradisional, saya akan melanjutkan belanja secara online sebanyak mungkin.

Teknik pengumpulan data yang digunakan dalam penelitian ini adalah angket. Angket disebarkan kepada 210 responden yang berisi tentang karakteristik responden dan item-item pernyataan tentang variabel penelitian.Skala pengukuran yang digunakan adalah skala likert.Metode pengumpulan data yang digunakan dalam penelitian ini dengan memberikan daftar pernyataan untuk diisi oleh para responden dan diminta untuk memberikan pendapat atau jawaban atas pernyataan yang diajukan (Somantri, 2006:37).

Teknik analisis data menggunakan path analysis. Setelah melalui uji validitas, diketahui bahwa semua itemitem pernyataan dalam indikator untuk variabel persepsi kemudahan, persepsi manfaat, kepuasan dan niat beli ulang secara onlinememiliki nilaicorrected item-total correlation lebih besar dari nila $r$ tabel $(0,30)$ sehingga dapat disimpulkan bahwa pernyataanpernyataan pada instrumen penelitian (angket) dinyatakan valid dan dapat digunakan sebagai alat ukur untuk 


\section{BISMA - Bisnis dan Manajemen -Volume 8 No. 2 Februari 2016}

mengukur pengaruh kepercayaan konsumen online dan kemudahan penggunaan.

Hal tersebut menunjukkan bahwa indikator dari masing-masing variabel dinyatakan valid atau dapat mengukur variabel-variabel tersebut dengan tepat. Setelah melalui uji reliabilitas, diketahui bahwa nilai Cronbach's Alpha untuk masing-masing variabel memiliki nilai lebih besar dari 0,70 sehingga dapat dinyatakan bahwa keseluruhan variabel memiliki reliabilitas yang baik.

\section{HASIL DAN PEMBAHASAN}

Sebelum melakukan pengujian dengan path analysis, dilakukan uji normalitas, liniearitas, dan outlier. Berdasarkan hasil analisis dengan menggunakan Amos 19 didapatkan hasil uji normalitas multivariate adalah sebesar -0,952 yang berada dalam selang
-2,58 hingga 2,58, sehingga dapat disimpulkan bahwa asumsi multivariate normality sudah terpenuhi. Berdasarkan hasil liniearitas dan outlier diketahui bahwa nilai sig. persepsi kemudahan, persepsi manfaat, kepuasan dan niat beli ulang secara online sebesar $0,000<0,05$, sehingga telah memenuhi syarat persepsi kemudahan, persepsi manfaat, kepuasan, dan niat beli ulang secara online bersifat linear. Nilai p2 juga tidak menunjukkan nilai kurang dari 0,05., sehingga dapat disimpulkan bahwa data pada penelitian ini memenuhi dan data layak digunakan dalam estimasi berikutnya.

Model analisis jalur pada penelitian ini untuk menggambarkan hubungan kausalitas yang diuji. Berikut hasil model analisis jalur yang telah diuji dalam penelitian ini:

\section{Gambar 1 Model Diagram Jalur}

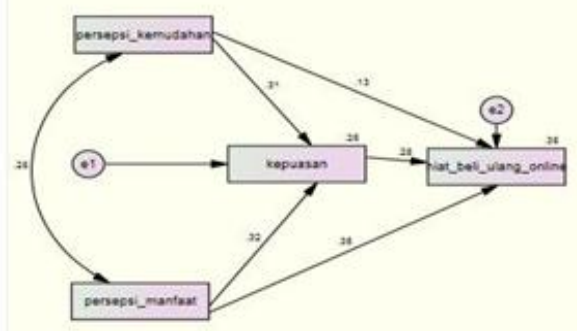

Berdasarkan model pada gambar 4.1 diatas dapat dikonversi kedalam persamaan model struktural. Menurut Sarwono (2012:15), untuk menghitung nilai e1 dan e2 dapat menggunakan rumus e $=$. Sehingga persamaan model struktural dalam penelitian ini adalah sebagai berikut:

$\mathrm{Z}=\mathrm{b} 1 \mathrm{X} 1+\mathrm{b} 2 \mathrm{X} 2+\mathrm{e} 1 \quad \mathrm{Z}=0,31$ $\mathrm{X}+0,32+0,967$
$\mathrm{Y}=\mathrm{b} 3 \mathrm{Z}+\mathrm{b} 4 \mathrm{X} 1+\mathrm{b} 5 \mathrm{X} 2+\mathrm{e} 2 \mathrm{Y}=0,28$ $\mathrm{X}+0,13 \mathrm{Z}+0,35+0,936$

Uji hipotesis ditentukan sebesar 0.05. apabila perbandingan nilai probabilitas signifikansi (p) lebih kecil bila dibandingkan dengan taraf signifikansi $(\alpha)$, maka hipotesis yang diajukan dapat diterima. Berikut hasil uji hipotesis dalam penelitian ini:

\section{Tabel 1 Hasil Uji Hipotesis}


Khoirul Basyar, Sanaji - Pengaruh Persepsi Kemudahan Dan Persepsi Manfaat ...

\begin{tabular}{|l|l|l|l|l|l|l|}
\hline \multicolumn{1}{|c|}{ Jalur } & $\begin{array}{c}\text { Koefisien } \\
\text { Regresi }\end{array}$ & \multicolumn{1}{|c|}{ Beta } & S.E. & CR Hitung & P & Simpulan \\
\hline PeoU $\rightarrow$ S & 0,281 & .310 & 0,056 & 4,979 & 0,000 & H1 diterima \\
\hline $\mathrm{PU} \longrightarrow \mathrm{S}$ & 0,272 & .318 & 0,053 & 5,100 & 0,000 & H2 diterima \\
\hline PU $\longrightarrow$ ORI & 0,238 & .280 & 0,055 & 4,345 & 0,000 & H3 diterima \\
\hline PeoU $\longrightarrow$ ORI & 0,102 & .134 & 0,047 & 2,174 & 0,030 & H4 diterima \\
\hline PU $\rightarrow$ ORI & 0,251 & .346 & 0,045 & 5,616 & 0,000 & H5 diterima \\
\hline
\end{tabular}

Sumber : Data diolah peneliti

Berdasarkan tabel 1 di atas dapat dijelaskan hasil uji hipotesis yaitu pada hipotesis pertama nilai probabilitas signifikansinya sebesar $0,000(\mathrm{p} \leq 0,05)$. Hal ini menunjukkan bahwa hipotesis pertama diterima. Pada hipotesis kedua terdapat nilai probabilitas signifikansinya sebesar $0,000(\mathrm{p} \leq 0,05)$. Hal ini menunjukkan bahwa hipotesis kedua diterima. Pada hipotesis ketiga terdapat nilai probabilitas signifikansinya sebesar $0,000(\mathrm{p} \leq 0,05)$. Hal ini menunjukkan bahwa hipotesis ketiga diterima. Pada hipotesis keempat terdapat nilai probabilitas signifikansinya sebesar $0,030(\mathrm{p} \leq 0,05)$. Hal ini menunjukkan bahwa hipotesis keempat diterima. Pada hipotesis kelima terdapat nilai probabilitas signifikansinya sebesar $0,000(\mathrm{p} \leq 0,05)$. Hal ini menunjukkan bahwa hipotesis kelima diterima.

\section{PEMBAHASAN}

\section{Pengaruh Persepsi Kemudahan Terhadap Kepuasan}

Hasil penelitian menunjukkan bahwa persepsi kemudahan memiliki hubungan positif dan pengaruh yang signifikan terhadap kepuasan, artinya semakin baik persepsi kemudahan, maka kepuasanjuga akan semakin meningkat.Konsumen harus merasakan puas terlebih dahulu agar konsumen berniat membeli ulang secara online. Dengan kemudahan mencari informasi produk, situs yang jelas dan mudah digunakan saat belanja online membuat konsumen akan semakin puas dalam berbelanja secara online. Jadi pelaku ecommerce harus memberikan kepusan kepada konsumennya terlebih dahulu agar berniat membeli ulang secara online.

Hasil tersebut mendukung penelitian yang dilakukan oleh Purwohandoko dkk., (2015) menyebutkan bahwa terdapat pengaruh positif antara persepsi kemudahan dengan kepuasan. Hasil tersebut menunjukkan bahwa persepsi kemudahan dapat semakin puas terhadap penggunaan teknologi baru. Serta penelitian dengan hasil yang sama dilakukan oleh Tu, et al., (2012) menyebutkan bahwa terdapat pengaruh 
yang signifikan antara persepsi kemudahan dengan kepuasan. Hasil tersebut menunjukkan bahwa persepsi kemudahan dapat membuat konsumen puas.

Dalam penelitian ini variabel persepsi kemudahan diukur dengan menggunakan empat indikator yaitu situs yang jelas dan dapat dimengerti, tidak memerlukan usaha yang berlebih, mudah untuk menemukan informasi yang dibutuhkan, mudah untuk digunakan. Berdasarkan hasil dari jawaban responden melalui pernyataanpernyataan dalam mengukur persepsi kemudahan, indikator situs yang jelas dan dapat dimengerti memiliki nilai ratarata tertinggi dimana sebagian besar responden menyatakan setuju bahwa responden percaya, situs belanja online jelas dan dapat dimengerti. Hal tersebut menunjukkan bahwa dalam melakukan belanja online, situs belanjaonline yang dikunjungi jelas dan dapat dimengerti. Jadi untuk pelaku bisnis e-commerce harus bisa memberikan kemudahan dalam penggunaan situs belanja online agar semakin jelas dan cepat dimengerti.

Pengaruh Persepsi Manfaat Terhadap Kepuasan

Hasil penelitian menunjukkan bahwa persepsi kemudahan memiliki hubungan positif dan pengaruh yang signifikan terhadap kepuasan, artinya semakin baik persepsi manfaat, maka kepuasanjuga akan semakin meningkat. Hal ini menunjukkan bahwa apabila semakin cepat dan lebih mudah melakukan belanja secara online maka semakin mempengaruhi kepuasan dalam belanja online. Jadi pelaku e-commerce harus memberikan kecepatan transaksi jual-beli secara online ketika konsumen berbelanja online. Dimulai dari proses pencarian barang, pembayaran dan proses pengiriman hingga sampai ditangan konsumen. Dan pada akhirnya konsumen akan puas dan akan berniat membeli ulang secara online.

Penelitian ini mendukung penelitian yang dilakukan oleh Trisnawati dkk., (2012) menyebutkan bahwa terdapat pengaruh positif antara persepsi manfaat terhadap kepuasan, artinya semakin baik persepsi manfaat, maka kepuasan juga akan semakin meningkat baik pada produk online Fesh Shop. Penelitian yang juga dilakukan oleh Wenet al., (2011) yang memberikan hasil bahwa variabel persepsi kemudahan secara signifikan berpengaruh positif terhadap kepuasan serta penelitian yang dilakukan oleh

Purwohandoko dkk., menyebutkan bahwa terdapat pengaruh positif antara persepsi manfaat dengan kepuasan. Hasil tersebut menunjukkan bahwa persepsi manfaat dapt menimbulkan individu menjadi semakin puas terhadap penggunaan teknologi baru.

Dalam penelitian ini variabel persepsi manfaat diukur dengan menggunakan lima indikator yaitu internet memudahkan berbelanja secara cepat, internet membuat keputusan pembelian yang lebih baik, internet sebagai belanja yang lebih berguna, belanja internet menghemat uang, internet lebih mudah untuk melakukan pembelian.

Berdasarkan hasil dari jawaban responden melalui pernyataanpernyataan dalam mengukur persepsi 
kemudahan, indikator internet membuat keputusan pembelian yang lebih baik memiliki nilai rata-rata tertinggi dimana sebagian besar responden menyatakan setuju bahwa responden percaya, belanja di situs belanja online membuat keputusan pembelian lebih baik. Hal tersebut menunjukkan bahwa dalam melakukan belanja online, belanja secara onlinemerupakan cara membuat keputusan pembelian yang lebih baik.Jadi para pelaku bisnis e-commerce harus lebih meningkatkan kesadaran kepada masyarakat agar lebih mekakukan belanja online.

\section{Pengaruh Kepuasan Terhadap Niat Beli Ulang Secara Online}

Hasil penelitian menunjukkan bahwa kepuasan memiliki hubungan positif dan pengaruh yang signifikan terhadap niat beli ulang secara online, artinya semakin baik kepuasan yang diberikan, maka niat beli ulang secara onlinejuga akan semakin meningkat. Hal ini menunjukkan bahwa apabila semakin puas dalam berbelanja online maka akan semakin mempengaruhi niat beli ulang dalam belanja online. Jadi pelaku ecommerceharus memberikan kepuasan terhadap konsumen agar konsumen berniat membeli ulang secara online. Penelitian ini mendukung penelitian yang dilakukan oleh

Trisnawati dkk.,

menyebutkan bahwa terdapat pengaruh positif antara kepuasan dengan niat pembelian ulang secara online. Hasil penelitian tersebut menunjukkan bahwa semakin baik kepuasan maka niat pembelian ulang secara onlinejuga akan semakin meningkatbaik pada produk online Fesh Shop.Hasil penelitian ini sejalan dengan penelitian yang dilakukan oleh Wenet al., (2011)yang memberikan hasil penelitian bahwa variabel kepuasan secara signifikan berpengaruh positif terhadap niat pembelian ulang secara online.Serta penelitian yang serupa yang dilakukan oleh

Siyamtinah dan Hendar (2015) yang memberikan hasil penelitian bahwa variabel kepuasan secara signifikan berpengaruh positif terhadap niat pembelian ulang secara online. Hasil tersebut menunjukkan semakin konsumen puas maka akan semakin positif niat pembelian ulang secara online.

Dalam penelitian ini variabel kepuasan diukur dengan menggunakan empat indikator yaitu saya sangat puas dengan keseluruhan pengalaman berbelanja online, saya sangat senang dengan keseluruhan pengalaman berbelanja online, saya sangat terpuaskan dengan keseluruhan pengalaman berbelanja online, saya sangat senang sekali dengan keseluruhan pengalaman berbelanja online. Berdasarkan hasil dari jawaban responden melalui pernyataanpernyataan dalam mengukur kepuasan, indikator saya sangat terpuaskan dengan keseluruhan pengalaman berbelanja online memiliki nilai rata-rata tertinggi dimana sebagian besar responden menyatakan setuju bahwa responden sangat terpuaskan dengan keseluruhan pengalaman berbelanja online. Hal tersebut menunjukkan bahwa responden dalam melakukan belanja online, terpuaskan dengan keseluruhan pengalaman belanja online mereka.Jadi 
para pelaku bisnis e-commerce harus lebih memuaskan para konsumennya agar konsumen terpuaskan dengan belanja online mereka

\section{Pengaruh Persepsi Kemudahan Terhadap Niat Beli Ulang Secara Online}

Hasil penelitian ini menunjukkan bahwa persepsi kemudahan memiliki hubungan positif dan pengaruh yang signifikan terhadap niat beli ulang secara online, artinya semakin baik persepsi manfaat, maka niat beli ulang secara online juga akan semakin meningkat.Hal ini menunjukkan bahwa apabila semakin jelas dan mudah melakukan belanja secara online maka akan semakin mempengaruhi niat beli ulang dalam belanja online.Jadi pelaku e-commerce harus memberikan kemudahan dalam penggunaan situs/toko online agar mudah digunakan dan memberikan kemudahan dalam pembayaran sehingga konsumen akan berniat membeli ulang secara online.

Penelitian ini mendukung oleh penelitian yang dilakukan oleh Har dan Eze (2011) dalam penelitiannya memberikan hasil bahwa persepsi kemudahan berpengaruh positif terhadap niat pembelian ulang secara online. Hasil tersebut menunjukkan semakin baik persepsi kemudahan maka akan semakin positif niat pembelian ulang secaraonline. Serta penelitian yang dilakukan oleh Adiutama dan Santika 2013 dalam penelitiannya memberikan hasil bahwa persepsi kemudahan penggunaan berpengaruh positif dan signifikanterhadap niat berbelanja kembali pada situs jual beli online Tokobagus.com, hal ini berarti semakin tinggi persepsi kemudahan penggunaan maka niat berbelanja kembali pada Tokobagus.com juga akan meningkat.

Dalam penelitian ini variabel niat beli ulang secara online diukur dengan menggunakan tiga indikator yaitu saya bermaksud melanjutkan menggunakan online shopping daripada menghentikannya, saya bermaksud menggunakan online shopping daripada belanja secara tradisional, jika saya bisa, saya melanjutkan belanja online sebanyak mungkin. Berdasarkan hasil dari jawaban responden melalui pernyataan-pernyataan dalam mengukur niat beli ulang secara online, indikator saya bermaksud menggunakan online shopping daripada belanja secara tradisional memiliki nilai rata-rata tertinggi dimana sebagian besar responden menyatakan setuju bahwa responden lebih menggunakan belanja secara online daripada belanja secara tradisional.Hal tersebut menunjukkan bahwa responden dalam melakukan belanja online, lebih menggunakan belanja secara online daripada belanja secara tradisional.Jadi para pelaku bisnis e-commerce harus lebih memberikan manfaat dengan berbelanja secara onlinekonsumen tidak membuang banyak waktu dalam berbelanja serta agar konsumen lebih mudah dalam menemukan produk yang dicari konsumen.

\section{Pengaruh Persepsi Manfaat Terhadap Niat Beli Ulang Secara Online}

Hasil penelitian menunjukkan bahwa persepsi kemudahan memiliki hubungan positif dan pengaruh yang signifikan terhadap niat beli ulang secara online, artinyasemakin baik persepsi 
manfaat, maka niat beli ulang secara online juga akan semakin meningkat. Tanpa harus puas dulu konsumen sudah berniat membeli ulang secara online.Dengan belanja di situs belanja online dapat dilakukan secara cepat dan lebih mudah melakukan pembelian membuat konsumen akan berniat membeli ulang secara online. Jadi perusahaan harus memberikan manfaat lebih terhadap situs belanja onlinemerekaagar semakin cepat dan mudah dalam melakukan transaksi jual belionline mereka agar mereka berniat membeli ulang secara online.

Penelitian ini mendukung penelitian yang dilakukan Trisnawati dkk., (2012) menyebutkan bahwa terdapat pengaruh positif antara persepsi manfaat dengan niat pembelian ulang online. Hasil penelitian ini menunjukkan persepsi manfaat yang dirasakan oleh para konsumen adalah konsumen yang telah mencapai tugas belanja yang efisien akan menunjukkan bahwa konsumen tersebut akan melakukan pembelian ulang terhadap produk Fesh Shop. Hasil penelitian ini sejalan dengan penelitian yang dilakukan oleh Har dan Eze (2011) dalam penelitiannya memberikan hasil bahwa persepsi manfaat berpengaruh positif terhadap niat beli ulang secaraonline. Serta penelitian yang dilakukan oleh Wenet al., (2011) yang memberikan hasil bahwa variabel persepsi manfaat secara signifikan berpengaruh positif terhadap niat beli ulang secara online.

Terdapat beberapa saran dari hasil dari penelitian diatas, yaitu hasil penelitian pada variabel persepsi kemudahan pada item yang berbunyi
"Saya percaya, situs belanja online mudah untuk menemukan informasi yang dibutuhkan" lebih rendah dibandingkan item pernyataan lainnya. Jadi pelaku bisnis e-commerce harus bisa memberikan kemudahan dalam memberikan informasi yang lengkap dan jelas terhadap produk yang dijualnya seperti menambahkan kategori produk yang spesifik dan memberikan fitur pencarian produk pada tokoonline mereka.

Kemudian hasil penelitian pada variabel persepsi manfaat pada item yang berbunyi "Saya percaya, belanja di situs belanja online akan bermanfaat bagi orang yang menggunakan" dan "Saya percaya, belanja di situs belanja online menghemat uang" lebih rendah dari item pernyataan lainnya. Jadi pelaku bisnis e-commerce harus memberikan manfaat lebih dari toko online mereka seperti memberikan efisiensi waktu dalam berbelanja online dan memberikan banyak diskon bagi pelanggan tetap /diskon pada pembelian dalam jumlah banyak.

Hasil penelitian pada variabel kepuasan pada item yang berbunyi "Saya sangat senang sekali dengan keseluruhan pengalaman berbelanja online" lebih rendah dari item pernyataan lainnya.Jadi para pelaku bisnis e-commerce harus memberikan kepuasan lebih agar konsumen semakin puas terhadap pengalaman belanja online mereka.

Dan hasil penelitian pada variabel kepuasan pada item yang berbunyi "Saya lebih melanjutkan belanja secara onlinedaripada menghentikannya" lebih rendah dari item pernyataan lainnya. Jadi pelaku e-commerce harus bisa membuat 
konsumen berniat membeli ulang secara online dengan memberikan kemudahan dalam bertransaksi contohnya dengan memberikan kemudahan dalam pembayaran transfer dengan memiliki banyak rekening bank, memberikan respon yang cepat kepada konsumen dan ramah terhadap konsumen, sehingga konsumen akan berniat membeli ulang.

\section{REFERENSI}

Adiutama, I Made Rendy Wicaksana dan

I Wayan Santika 2013. Pengaruh persepsi kemudahan penggunaan, kegunaan yang dirasakan, dan tingkat pendidikan terhadap niat berbelanja kembali pada situs Tokobagus.com. (ojs.unud.ac.id). Diakses pada tanggal 25 Desember 2015

Andriani, Vivi. 2015. Pengaruh Kualitas Situs Jejaring Sosial Terhadap Niat Beli Ulang Secara Online Dengan Kepuasan Sebagai Variabel Intervening. Skripsi tidak diterbitkan. Surabaya.

Universitas Negeri Surabaya

Cheung, Christy M., K. Zhu, Lei., Kwong, Timothy., Chan, Gloria W.W., dan Limayem, Moez. 2003.

Online consumer behavior: a review Journal of Electronic Commerce. Volume 7(3), pp. 69-103

Purwohandoko., Sanaji., dan Mustofa, Ali. 2015. The Successful Implementation of E-Budgeting In Public University: A Study at Individual Level. Journal of Advances in Information Technology, Vol.6 No.3 Surabaya

Sarwono, Jonathan. 2012. Path Analisis dengan SPSS: Teori, Aplikasi, and agenda for future research. (ejournal.narotama.ac.id) Diaks espadatanggal6 September 2015

Davis, F. D., 1989. Perceived Usefulness, Perceived Ease of Use, and User Acceptance of Information Technology. MIS quarterly. Volume. 13(3), pp. 319-340.

Har,Lee Chai and Eze, Uchenna Cyril. 2011. Factors influence consumers' intention to repurchase online in Malaysia. International Journal of Electronic Commerce Studies.Volume. 2, No.2, pp. 157164.

Kyauk, Sai Tip. And Chaipoopirutana, Sirion.2014. Factors Influencing Repurchase Intention:A Case Study of Xyz.Com Online Shopping Website in Myanmar.Journal International Conference on Trends in Economic, Humanities and Management. (http://dx.doi.org)

Pavlou, P. A., 2003. Consumer Acceptance of Electronic Commerce: Integrating Trust and Risk with The Technology Acceptance Model. International

Prosedur Analisis untuk Riset Skripsi, Tesis dan Disertasi. Jakarta : PT Gramedia

Siyamtinah dan Hendar. 2015. Meningkatkan Pembelian Ulang Melalui Kepercayaan dan Kepuasan Pada Pembelanjaan Online. ISSN 2302 - 9791 Vol.2 No.1 Semarang Somantri, Ating. 2006. Aplikasi Statistika dalam Penelitian. Bandung: Pustaka Setia. 
Trisnawati, Ella. Suroso, Agus. Dan Kumorohadi, Untung. 2012. Analisis faktor-faktor kunci dari niat pembelian kembali secara online (studi kasus pada konsumen fesh shop). Jurnal Bisnis dan Ekonomi. Vol.19 No. 2 September

Tu, Chien-Chung., Kwoting

Fang., and Chwen-Yea Lin 2012."Perceived Ease of Use, Trust, and Satisfaction as Determinants of Loyalty in eAuction Marketplace".Journal of Computers, VOL. 7, NO. 3, Taiwan Wen, Chao., Prybutok, Victor R., and $\mathrm{Xu}$, Chenyan2011. "An Integrated Model for CustomerOnline Repurchase Intention”. 2011. Journal of Computer Information Systems. Journal of Computer Information System. (www.iacis.org). Diakses pada tanggal 15 Juli 2015

www.bisnis.com. 84\% konsumen tak puas belanja online.Diakses pada tanggal 03 Maret 2014

www.apjii.or.id. Profil penggunga internet Indonesia 2014. Diakses pada 1 Agustus 2015

www.jpnn.com. Perkembangan bisnis E-Commerce di Indonesia. Diakses pada 28 Maret 2016

Yolanda, Arabella. 2013. Pengaruh Persepsi Manfaat, Persepsi Kemudahaan, Persepsi Kenyamanan, Dan Norma Subjektif Terhadap Minat Menggunakan Electronic Commerce (Ecommerce. Jurnal Ilmiah Mahasiswa FEB. Vol.2 No.2 Malang. 